Article

\title{
Diversity Oriented Design of Various Benzophenone Derivatives and Their in Vitro Antifungal and Antibacterial Activities
}

\author{
Li Sun, Jie Wu, Min Luo, Xiaoli Wang, Man Pan, Zhaopin Gou and Dequn Sun *
}

Marine College, Shandong University, Weihai Wenhua West Road, No.180, Weihai 264209, China

* Author to whom correspondence should be addressed; E-Mail: dequn.sun@sdu.edu.cn;

Tel.: +86-631-568-8537; Fax: +86-631-568-8303.

Received: 3 October 2011; in revised form: 9 November 2011 / Accepted: 14 November 2011 /

Published: 23 November 2011

\begin{abstract}
A series of new substituted benzophenone derivatives was designed, synthesized and screened for their antifungal and antibacterial activities. The bioassays indicated that most of the synthesized compounds showed some antifungal activity against the tested phytopathogenic fungi, but lower antibacterial activities towards the five vibrios isolated from marine sources. The preliminary structure activity relationship (SAR) of the compounds was also discussed.
\end{abstract}

Keywords: benzophenone derivatives; bioactivity; phytopathogenic fungi; vibrio

\section{Introduction}

Resistance and cross-resistance are easily found in the field when a class of agrochemicals has been used for a long time [1], thus exploring new agrochemical candidates with different modes of action is always meaningful. Metrafenone (I, Figure 1) is a novel benzophenone-derived fungicide [2] recently registered in several countries for control of powdery mildews in different crops $[3,4]$ and eye spot in cereals [5]. It possess a different mode of action that might interfere with processes which are essential to establish and maintain polar action organization [6]. The carboxylic acid amide (CAA) fungicides, dimethomorph (II, Figure 1) and flumorph (III, Figure 1) [7,8] are derivatives of benzophenone and are common agrochemicals in the field in China nowadays. They have been widely used for years to control the diseases caused by Oomycete foliar plant pathogens (e.g., Phytophthora infestans (Mont.) de Bary and Peronosporaceae) with the mode of inhibiting cellulose synthesis [8]. Recently, Qin [9] 
synthesized a novel fungicide, pyrimorph (IV, Figure 1), which was actually an analog of II and III and exhibited excellent activity against oomycetes. Dimethomorph, flumorph and pyrimorph have both a benzophenone skeleton and a morpholine ring in their chemical structures. The morpholine group is likely to be a pharmacophore in fungicidal chemicals since it exists in a number of other commercial fungicides, such as tridemorph (V, Figure 1), dodemorph (VI, Figure 1) and fenpropimorph (VII, Figure 1) [10].

Figure 1. The chemical structures of several commercial fungicides.<smiles>COc1cc(C)c(C(=O)c2c(C)ccc(Br)c2C)c(OC)c1OC</smiles>

I metrafenone<smiles>CCC(C)(C)N1CC(C)OC(C)C1</smiles>

V tridemorph<smiles>[X]c1ccc(/C(=C/C(=O)N2CCOCC2)c2ccc(OC)c(OC)c2)cc1</smiles>

II $\mathrm{X}=\mathrm{Cl}$ dimethomorph

III $X=F$ flumorph<smiles>CC1CN(C2CCCCCCCCC2)CC(C)O1</smiles>

VI dodemorph<smiles>CC(C)(C)c1ccc(/C=C/C(=O)N2CCOCC2)cc1</smiles>

IV pyrimorph<smiles>CC(Cc1ccc(C(C)(C)C)cc1)CN1CC(C)OC(C)C1</smiles>

VII fenpropimorph

To the best of our knowledge, studies concerning metrafenone analogs as antifungal or antibacterial agents have seldom been reported. In an attempt to screen for new agrochemicals and predict their relatively detailed SAR, a diverse series of benzophenone derivatives, some of which contained a morpholine group, were designed on the basis of bioisosterism principles [11] and synthesized (Schemes 1-3). Among the compounds, twelve new compounds and five known compounds were tested on the phytopathogenic fungi and vibrios. Compounds 1b [12] and 3a [13] were synthesized before, but no studies on their bioactivity were reported. The silica gel-mediated synthesis and cytotoxic activity of 1c were reported [14]. Compound 1d was studied by Jie [15] with respect to its potential antiproliferative activity. Compounds $\mathbf{1 e}$ and $\mathbf{3 b}$ were already reported in our previous work [16].

As suggested by the SAR of metrofenone, one benzene ring of metrafenone was replaced by other potentially active moieties, such as aryl, aryloxy or aromatic heterocycles to give the first kind of new benzophenone derivatives 1a-e (Scheme 1). The second series of novel substituted benzophenone derivatives 3a, 3b and 3c, containing morpholine groups, were synthesized as shown in Scheme 2. 
Scheme 1. The synthetic routes of compounds $\mathbf{1 a}-\mathbf{e}$.<smiles>[X]c1ccc(C(=O)c2c(C)cc(OC)c(OC)c2OC)cc1</smiles><smiles>[R1]C(=O)c1cc(OC)c(OC)c(OC)c1</smiles>

$1(\mathrm{c}-\mathrm{e})$

EDCI: 1-(3-Dimethylaminopropyl)-3-ethylcarbodiimide hydrochloride

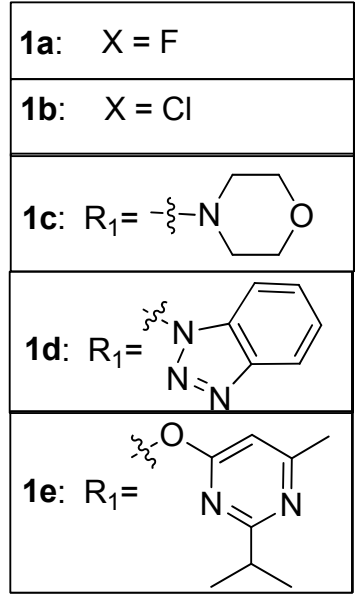

Scheme 2. The synthetic routes of compounds $\mathbf{3 a}-\mathbf{c}$.

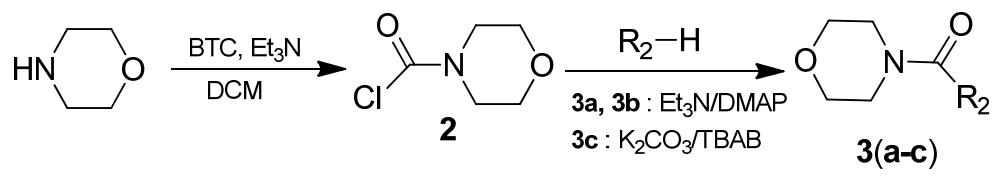

BTC: triphosgene

DMAP: 4-dimethylamiopryidine

TBAB: Tetrabutyl ammonium bromide

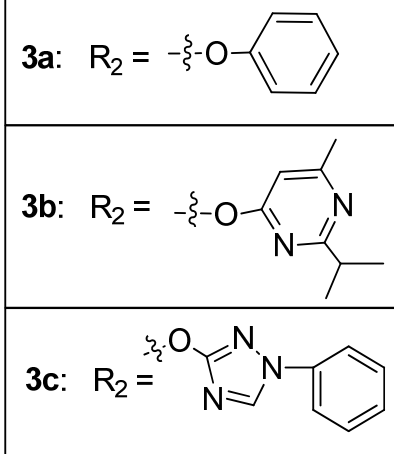

To learn more about SAR of the compounds containing benzophenone skeletons and morpholine groups, the new oxime derivatives 7 were designed by replacing the $\mathrm{C}$ atom of dimethomorph or flumorph with an isosteric $\mathrm{N}$ atom, and after reduction of the double bond, ethers $\mathbf{9}$ and amines $\mathbf{1 1}$ were obtained (Scheme 3).

Scheme 3. The synthetic routes of compounds 7,9 and 11.

oximes

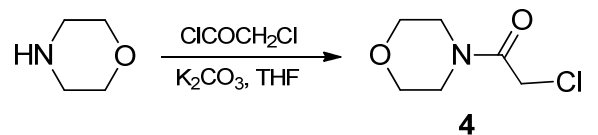<smiles>[X]c1ccc(C(=O)Cl)cc1</smiles><smiles>[X]c1ccc(C(=O)c2ccc(OC)c(OC)c2)cc1</smiles>

5a: $\mathrm{X}=\mathrm{F}$

5b: $\mathrm{X}=\mathrm{Cl}$<smiles>[X]c1ccc(/C(=N/O)c2ccc(OC)c(OC)c2)cc1</smiles>

6a: $X=F$

6b: $\mathrm{X}=\mathrm{Cl}$<smiles>[R3]ON=C(c1ccc([X])cc1)c1ccc(OC)c(OC)c1</smiles>

7 (a-d)

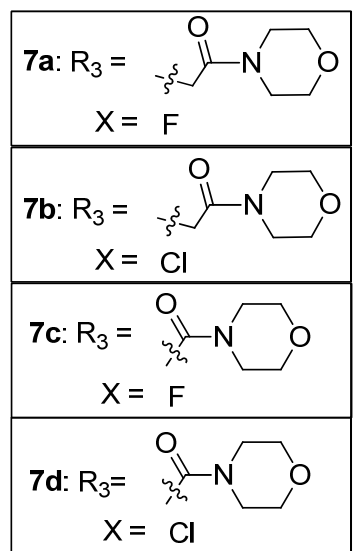


Scheme 3. Cont.

ethers

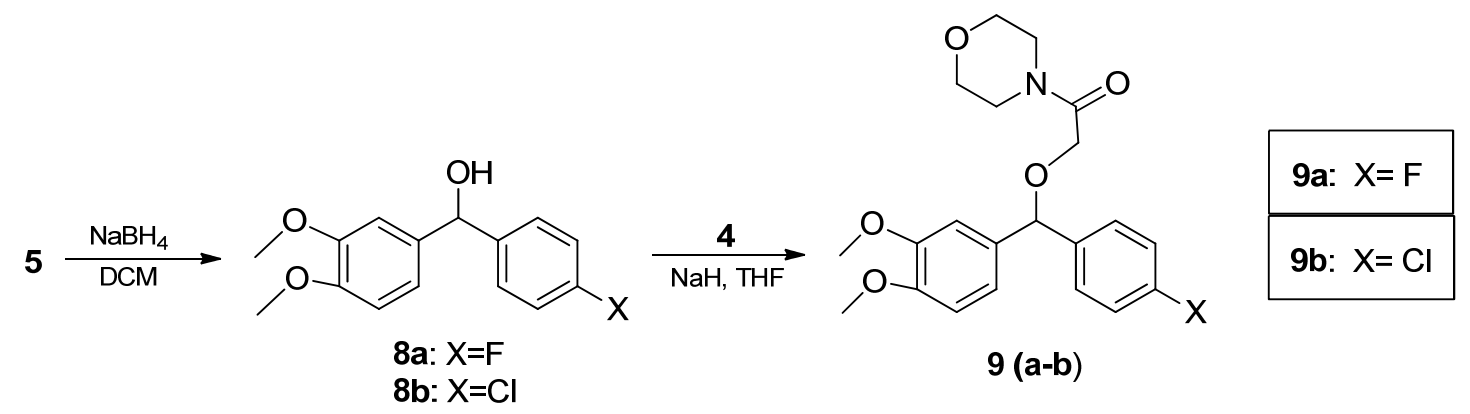

amines

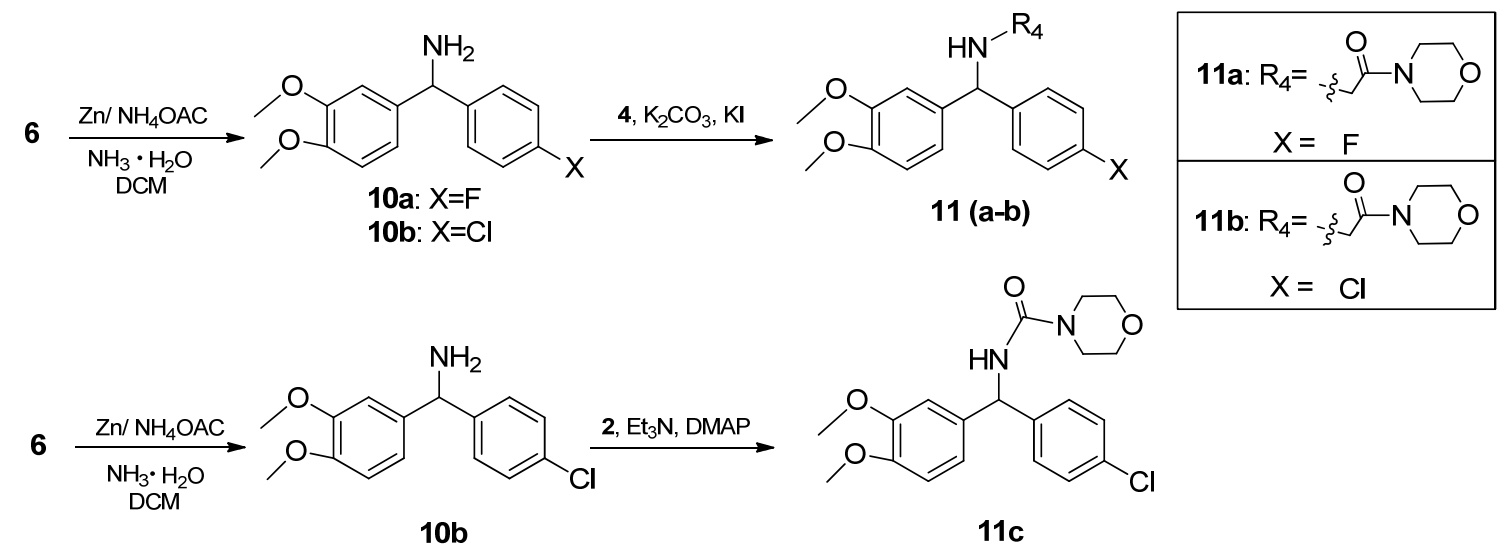

\section{Results and Discussion}

\subsection{Chemistry}

As shown in Scheme 1, 1a and 1b were synthesized via the classic Friedel-Crafts reaction from the appropriate benzoyl chlorides and 3,4,5-trimethoxytoluene. Compound $\mathbf{1 b}$ was also synthesized using a different method from the literature [12] in similar yield. Oxidation of the methyl group on 3,4,5trimethoxytoluene followed by condensation with morpholine, 6-hydroxy-2-isopropyl-4-methylpyrimidine and $1 H$-benzotriazole gave $\mathbf{1 c}, \mathbf{1 d}$ and $\mathbf{1 e}$, respectively. Compounds $\mathbf{3 a}$ and $\mathbf{3 c}$ were prepared using $\mathrm{Et}_{3} \mathrm{~N}$ and DMAP in DCM (73\% and $72 \%$ respectively) and $3 \mathrm{c}$ was obtained using $\mathrm{K}_{2} \mathrm{CO}_{3}$ and $\mathrm{TBAB}$ in DCM in a yield of $63 \%$.

The synthetic routes to $\mathbf{7 , 9}$ and $\mathbf{1 1}$ are outlined in Scheme 3. The benzophenone skeleton (compound 5) was synthesized from the 4-halosubstituted benzoyl chloride and 1,2-dimethoxybenzene starting materials via the classic Friedel-Crafts reaction. Compound $\mathbf{6}$ was obtained (in $96.7 \%$ yield) through coupling of 5 with $\mathrm{NH}_{4} \mathrm{OH} \cdot \mathrm{HCl}$ using $\mathrm{CH}_{3} \mathrm{COONa}$ as base and the generated $\mathrm{CH}_{3} \mathrm{COOH}$ as catalyst. The etherification reaction between compound 6 and 4 gave $7 \mathbf{a}$ and $7 \mathbf{b}$, the esterification reaction between $\mathbf{6}$ and $\mathbf{2}$ gave $7 \mathrm{c}$ and $\mathbf{7 d}$ under the corresponding conditions with good conversion.

The substituted benzophenone 5 was reduced to diphenyl methanol 8 with $\mathrm{NaBH}_{4}$ in DCM cleanly and almost quantitatively (98\%). Etherification of $\mathbf{8}$ with 4-(2-chloroacetyl) morpholine (4) gave 9a and $9 \mathbf{b}$ in yields of $91 \%$ and $84 \%$ respectively using $\mathrm{NaH}$ in THF. Reductive ammoniation of compound 6 with zinc dust in 30\% ammonia afforded amine 10, which was treated with 4 in the 
presence of $\mathrm{K}_{2} \mathrm{CO}_{3}$ and $\mathrm{KI}$ to give 11a and 11b or with 2 using $\mathrm{Et}_{3} \mathrm{~N}$ and DMAP to give 11c with yields higher than $70 \%$.

\subsection{Bioactivity}

All of the tested compounds had the purity of more than $95 \%$. The oximes were tested using a mixture of $(Z)$ - and $(E)$-isomers and the enantiomers were tested as racemic mixtures. The bioactivities towards phytopathogenic fungi and five vibrios were evaluated. The phytopathogenic fungi chosen included Alternaria kukuchiana (AK), Alternaria mali (AM), Botrytis cinerea (BC), Bipolaris maydi (BM), Cercospora arachidicola (CA), Gibberella zeae (GZ), Gibberella fujikuroi (GF), Macrophoma kuwatsukai (MK), Rhizoctonia solani (RS), Sclerotinia sclerotiorum (SS), Thanatephorus cucumeris (Frank), Domk (TC) and Fusarium oxysporum f. sp. Vasinfectum. All these fungi are different typical genera, often found in the Chinese agro-ecosystem. The five tested vibrios (Vibrio Parahaemolyticus, Vibrio harvyi, Vibrio anguillarum, Vibrio alginolyticus, Vibrio vulnificus) were isolated from marine organism. The bioactivity results are outlined in Tables respectively.

\subsubsection{Antifungal Activity to Phytopathogenic Fungi}

2.2.1.1. Antifungal Activity of Compounds 1 to ten Phytopathogenic Fungi

Table 1. The antifungal activity of the synthesized compounds $\mathbf{1}$.

\begin{tabular}{ccccccccccc}
\hline \multirow{2}{*}{$\begin{array}{c}\text { Compd. } \\
\text { No. }\end{array}$} & \multicolumn{8}{c}{ Fungicidal activities $\mathbf{( 5 0} \boldsymbol{\mu g} / \mathbf{m L}$, inhibition rate \%) } \\
\cline { 2 - 13 } & AK & BC & BM & CA & GF & GZ & MK & RS & SS & TC \\
\hline 1a & 45.5 & 7.4 & 34.8 & 6.7 & 33.3 & 11.1 & 0 & 66.7 & 0 & 21.6 \\
1b & 53.6 & 11.1 & 35.1 & 4.5 & 39.2 & 7.8 & 0 & 68.3 & 0 & 33.3 \\
1c & 22.7 & 11.1 & 8.7 & 20 & 6.7 & 3.7 & 37.5 & 44.4 & 13.3 & 7.8 \\
1d & 22.7 & 7.4 & 13.0 & 0 & 20 & 3.7 & 37.5 & 61.9 & 6.7 & 3.9 \\
1e & 31.8 & 14.8 & 26.1 & 6.7 & 20 & 7.4 & 40.6 & 63.5 & 66.7 & 9.8 \\
Flu. & 18.2 & 7.4 & 17.4 & 0 & 13.3 & 7.4 & 21.9 & 61.9 & 0 & 9.8 \\
Dim. & 22.7 & 18.5 & 17.4 & 0 & 20 & 0 & 6.3 & 68.3 & 20 & 23.5 \\
\hline
\end{tabular}

Flu. $=$ flumorph, Dim. $=$ dimethomorph .

Among compounds 1 (Table 1), more than one compound showed similar or better activity than flumorph and dimethomorph towards the tested fungi. Compounds $\mathbf{1 a}$ and $\mathbf{1 b}$ were more potent to most of the tested fungi belonging to the different genera. Both 1c and 1e had certain inhibitory activity against all of the tested fungi. Compound 1e containing a 3,4,5-trimethoxybenzene ring and pyrimidine group exhibited good activity compared to controls, especially to MK and SS, while 1e showed remarkable inhibition rates that were about 1 -fold and 2-fold higher than controls, respectively (40.6\%/21.9\%, 66.7\%/20\%). It's interesting that compounds 1c-1e all had activity on MK and SS, while 1a and $\mathbf{1 b}$ had no effect, which suggested that $\mathrm{N}$-containing heterocycles might be the necessary groups to inhibit MK and SS. Compounds 1a, $\mathbf{1 b}$ and $\mathbf{1 e}$ could be better fungicidal candidates since they showed better inhibition rates and relatively good broad-spectrum activity towards the tested fungi of diverse genera. 


\subsubsection{Antifungal Activity of Compounds 3 to Nine Phytopathogenic Fungi}

After the 3,4,5-trimethoxybenzene rings in 1c, 1d and 1e were replaced by morpholine groups to obtain new compounds, the structures of which are very different from metrofenone and flumorph or dimethomorph, compounds 3a-c showed similar or higher activity to nine fungi compared with flumorph and dimethomorph. Compounds $\mathbf{3 b}$ and $\mathbf{3 c}$ showed better broad-spectrum activity. According to the SAR discussion on compounds $\mathbf{1}$ and $\mathbf{3}$, a trimethoxybenzene ring was favorable for increased fungicidal activity.

Table 2. The antifungal activities of compounds 3.

\begin{tabular}{cccccccccc}
\hline Compd. & \multicolumn{8}{c}{ Fungicidal activities $\mathbf{( 5 0} \boldsymbol{\mu g} / \mathbf{m L}$, inhibition rate $\%)$} \\
\cline { 2 - 11 } No. & AK & BC & BM & CA & GF & GZ & MK & RS & TC \\
\hline 3a & 22.7 & 7.4 & 17.4 & 6.7 & 20 & 22.2 & 21.9 & 65.1 & 0 \\
3b & 40.9 & 18.5 & 17.4 & 6.7 & 6.7 & 7.4 & 31.3 & 61.9 & 19.6 \\
3c & 13.6 & 14.8 & 30.4 & 6.7 & 13.3 & 7.4 & 28.1 & 57.1 & 23.5 \\
Flu. & 18.2 & 7.4 & 17.4 & 0 & 13.3 & 7.4 & 21.9 & 61.9 & 9.8 \\
Dim. & 22.7 & 18.5 & 17.4 & 0 & 20 & 0 & 6.3 & 68.3 & 23.5 \\
\hline
\end{tabular}

\subsubsection{Antifungal Activity of Compounds 7, 9 and $\mathbf{1 1}$ to ten Phytopathogenic Fungi}

As shown in Table 3, compounds 7c and 11a displayed better wide-spectrum activity than the controls. Compound 9b showed significant inhibition of endophytic Alternaria spp. fungi such as AK and $\operatorname{AM}(27.3 \%$ and $57.1 \%$, respectively).

Table 3. The antifungal activities of 7, 9 and $\mathbf{1 1}$.

\begin{tabular}{|c|c|c|c|c|c|c|c|c|c|c|}
\hline \multirow{2}{*}{$\begin{array}{c}\text { Compd. } \\
\text { No. }\end{array}$} & \multicolumn{10}{|c|}{ Fungicidal activities $(50 \mu \mathrm{g} / \mathrm{mL}$, inhibition rate $\%)$} \\
\hline & $\mathbf{A K}$ & $\mathbf{A M}$ & BC & $\mathbf{B M}$ & $\mathbf{C A}$ & GF & GZ & MK & $\mathbf{R S}$ & TC \\
\hline $7 \mathbf{a}$ & 18.2 & 0 & 7.4 & 13.0 & 20 & 20 & 7.4 & 12.5 & 68.3 & 0 \\
\hline $7 b$ & 22.7 & 0 & 14.8 & 13.0 & 6.7 & 20 & 11.1 & 25.0 & 61.9 & 3.9 \\
\hline $7 c$ & 22.7 & 7.1 & 11.1 & 26.1 & 20 & 6.7 & 7.4 & 18.8 & 65.1 & 5.9 \\
\hline $7 d$ & 27.3 & 0 & 3.7 & 34.8 & 6.7 & 20 & 14.8 & 0 & 61.9 & 27.5 \\
\hline 9a & 18.2 & 14.3 & 3.7 & 17.4 & 6.7 & 20 & 7.4 & 18.8 & 63.5 & 0 \\
\hline $9 b$ & 27.3 & 57.1 & 3.7 & 13.0 & 0 & 6.7 & 0 & 18.8 & 63.5 & 2.0 \\
\hline 11a & 13.6 & 7.1 & 22.2 & 13.0 & 6.7 & 13.3 & 14.8 & 6.3 & 54.0 & 2.0 \\
\hline $11 b$ & 18.2 & 0 & 7.4 & 13.0 & 13.3 & 13.3 & 0 & 15.6 & 54.0 & 0 \\
\hline $11 \mathrm{c}$ & 18.2 & 14.3 & 11.1 & 13.0 & 0 & 13.3 & 3.7 & 40.6 & 58.7 & 15.7 \\
\hline Flu. & 18.2 & 21.4 & 7.4 & 17.4 & 0 & 13.3 & 7.4 & 21.9 & 61.9 & 9.8 \\
\hline Dim. & 22.7 & 7.1 & 18.5 & 17.4 & 0 & 20 & 0 & 6.3 & 68.3 & 23.5 \\
\hline
\end{tabular}

Replacement of the $\mathrm{F}$ atom on the benzene ring of 7a, 7c, 9a, 11a with $\mathrm{Cl}(\mathbf{7 b}, 7 \mathbf{d}, 9 \mathbf{b}, 1 \mathbf{b})$ led to a lightly increase in the inhibition of AK $(18.2 \% / 27.3 \%, 13.6 \% / 18.2 \%, 18.2 \%, 22.7 \%, 22.7 \% / 27.3 \%$, respectively). Introduction of a $-\mathrm{CH}_{2}$ into the bridge between the morpholine group and the substituted benzophenone skeleton was favorable to the antifungal activity against AM; for example, $9 \mathbf{b}$ was much more potent $(57.1 \%)$ than dimethomorph $(7.1 \%)$ and flumorph $(21.4 \%)$; with respect to CA, most of the compounds showed activities, except 9b, 11c $(0 \%)$, while flumorph and dimethomorph had no 
effect. Among the tested compounds, derivatives containing $\mathrm{C}=\mathrm{N}, \mathrm{F}$ and morpholine moieties such as $7 \mathbf{a}, 7 \mathbf{c}$ exhibited relatively higher inhibition rates $(20 \%, 20 \%)$ than others $(13.3 \%, 6.7 \%$ or 0$)$ towards CA.

\subsubsection{Antifungal Activity Towards Fusarium oxysporum f. sp. Vasinfectum}

Fusarium wilt, the "cancer" of cotton, caused by Fusarium oxysporum $f$. sp. vasinfectum is a global and serious threat to cotton, which is a high-value crop [17]. The pesticides carbendazim and dimethomorph are the two main chemicals used widely to prevent Fusarium wilt of cotton in the field in China, therefore carbendazim and dimethomorph were used as positive controls, and the antifungal

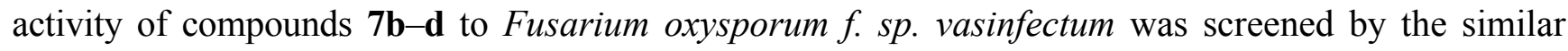
poisoned food technique at the concentrations of 500, 250 and $125 \mu \mathrm{g} / \mathrm{mL}$, respectively (Table 4). Compounds $\mathbf{7 b}-\mathbf{d}$ all have higher activity than dimethomorph at different concentrations and this result revealed that replacing the $\mathrm{C}$ atom in dimethomorph with an isosteric atom $\mathrm{N}$ results in higher activity to Fusarium wilt; furthermore, inserting one $\mathrm{CH}_{2}$ the between carbonyl and oxygen in $\mathbf{7 b}$ enhanced the activity, especially at the higher concentration. The $\mathrm{Cl}$ substituted compound $\mathbf{7 d}$ is more potent than the F substituted compound 7c.

It was interesting that $\mathbf{7 b}$ showed better inhibition at the concentration of $500 \mu \mathrm{g} / \mathrm{mL}$ but lower activity than carbendazim at the concentrations of 250 and $125 \mu \mathrm{g} / \mathrm{mL}$, indicating that $7 \mathbf{b}$ might have a lower concentration than carbendazim when the inhibition rate reached to $100 \%$. It might be better choice than carbendazim and represent another type of compound to prevent Fusarium wilt since its structure is totally different from carbendazim and might possess a different mode of inhibitory action.

Table 4. The inhibition rates to Fusarium oxisporum f. sp. Vasinfectum.

\begin{tabular}{cccccc}
\hline & $\mathbf{5 0 0} \boldsymbol{\mu g} / \mathbf{m L}$ & \multicolumn{2}{c}{$\mathbf{2 5 0} \boldsymbol{\mu g} / \mathbf{m L}$} & \multicolumn{2}{c}{$\mathbf{1 2 5} \boldsymbol{\mu g} / \mathbf{m L}$} \\
\hline Compd. & Inhibition rate (\%) & Compd. & Inhibition rate (\%) & Compd. & Inhibition rate (\%) \\
\hline Carb. & 44.2 & Carb. & 39.3 & Carb. & 33.0 \\
Dim. & 12.5 & Dim. & 5.9 & Dim. & 3.1 \\
$\mathbf{7 b}$ & 50.0 & $\mathbf{7 b}$ & 19.7 & $\mathbf{7 b}$ & 5.8 \\
$\mathbf{7 c}$ & 27.4 & $\mathbf{7 c}$ & 10.6 & $\mathbf{7 c}$ & 3.9 \\
$\mathbf{7 d}$ & 33.1 & $\mathbf{7 d}$ & 13.3 & $\mathbf{7 d}$ & 4.7 \\
\hline
\end{tabular}

Carb.: carbendazim.

\subsubsection{Antibacterial Activity Towards Five Vibrios}

Vibrios cause vibriosis, a common disease in marine aquaculture worldwide and a number of species are also human pathogens [18]. Antibiotics are widely used to treat vibrios and the most potent compounds are used to control vibriosis, which increases the resistance of the bacteria to commercially available antibiotics $[19,20]$, in addition to their negative impact on the environment and residues in cultured marine animals. Nowadays, though many studies focus on the bacterial sensitivity to the extracts from seaweed or herbal plants, and discovery of the bacterial biocontrol agents [21], there are few reports about screening of synthetic compounds as potential bactericides which have good activity against vibrios. Therefore, the synthesized compounds were tested on five vibrios by simplified disc diffusion method [22]. Unfortunately, they exhibited different levels of inhibitory effects against the 
five vibrios at a relatively high concentration and were all much less effective than streptomycin and gentamicin sulfate.

\section{Experimental}

\subsection{Chemistry}

\subsubsection{General}

Anhydrous solvents were distilled prior to use. All reactions using air- or moisture-sensitive reagents were conducted under an inert nitrogen atmosphere. The products were purified by column chromatography using silica gel (200-300 mesh). Melting points of the products were determined in open capillary tubes and are uncorrected. The IR spectra were recorded on a Bruker VERTEX 70 FT-IR instrument. ${ }^{1}$ H-NMR spectra were recorded on Varian-400 at r.t. using TMS as an internal reference. Mass spectra were recorded with a JEOL MS-D 300 mass spectrometer. Elemental analysis was performed on a Carlo-1106 model automatic instrument.

\subsubsection{Syntheses}

(4-Fluorophenyl)(2,3,4-trimethoxy-6-methylphenyl)methanone (1a). A suspension of $\mathrm{AlCl}_{3}(0.52 \mathrm{~g}$, $3.9 \mathrm{mmol})$ in DCM $(35 \mathrm{~mL})$ was placed in a salt-ice bath for 10 minutes. After a solution of 3,4,5trimethoxytoluene $(0.55 \mathrm{~g}, 3 \mathrm{mmol})$ in DCM $(10 \mathrm{~mL})$ was added dropwise, 4-fluorobenzoyl chloride (0.62 g, $3.9 \mathrm{mmol})$ dissolved in DCM $(15 \mathrm{~mL})$ was slowly added dropwise at the same temperature. The resulting yellow solution was warmed to room temperature and stirred for $8 \mathrm{~h}$. The mixture was washed by $0.5 \mathrm{~N} \mathrm{HCl}$ aqueous $(20 \mathrm{~mL} \times 2)$ and the water layer was extracted with $\mathrm{DCM}(30 \mathrm{~mL})$ once. The combined DCM layer was washed with sat. $\mathrm{Na}_{2} \mathrm{CO}_{3}$ and water, respectively, dried over anhydrous $\mathrm{MgSO}_{4}$, and concentrated to give a crude product which was purified by column chromatography (petroleum: ethyl acetate $\left.3: 1, \mathrm{R}_{\mathrm{f}}=0.18\right)$ to give compound $\mathbf{1 a}$ as a white solid $(0.59 \mathrm{~g}, 65 \%)$, $\mathrm{mp}$ 114-116 ${ }^{\circ} \mathrm{C}$; IR (film, $\mathrm{cm}^{-1}$ ) 2939, 2841, 1730, 1670, 1597, 1502, 1332, 1228, 1199, 1151, 1118, 989, 858; ${ }^{1} \mathrm{H}-\mathrm{NMR}\left(\mathrm{CDCl}_{3}, 300 \mathrm{MHz}\right) \delta(\mathrm{ppm}): 2.11\left(\mathrm{~s}, 3 \mathrm{H}, \mathrm{CH}_{3}\right), 3.69\left(\mathrm{~s}, 3 \mathrm{H}, \mathrm{OCH}_{3}\right), 3.85\left(\mathrm{~s}, 3 \mathrm{H}, \mathrm{OCH}_{3}\right)$, 3.89 (s, 3H, $\left.\mathrm{OCH}_{3}\right), 6.55$ (s, 1H, Ph-H), 7.08-7.15 (m, 2H, Ph-H), 7.81-7.87 (m, 2H, Ph-H). m/z (EI) $304\left(\mathrm{M}^{+}\right)$. Anal. Calc. for $\mathrm{C}_{17} \mathrm{H}_{17} \mathrm{FO}_{4}$ (304.31): C, 67.10; H, 5.63; found: C, 67.07; H, 5.66.

(4-Chlorophenyl)(2,3,4-trimethoxy-6-methylphenyl)methanone (1b). 1b was prepared from 3,4,5trimethoxytoluene and 4-chlorobenzoyl chloride using the same procedure as described for $\mathbf{1 a}$ to afford a white solid (69\%). mp 99-101 ${ }^{\circ} \mathrm{C}$ (lit. 99.5-100.0 $\left.{ }^{\circ} \mathrm{C}\right)$ [12]; ${ }^{1} \mathrm{H}-\mathrm{NMR}\left(\mathrm{CDCl}_{3}, 400 \mathrm{MHz}\right) \delta(\mathrm{ppm})$ : $2.15\left(\mathrm{~s}, 3 \mathrm{H}, \mathrm{CH}_{3}\right), 3.67\left(\mathrm{~s}, 3 \mathrm{H}, \mathrm{OCH}_{3}\right), 3.74\left(\mathrm{~s}, 3 \mathrm{H}, \mathrm{OCH}_{3}\right), 3.83\left(\mathrm{~s}, 3 \mathrm{H}, \mathrm{OCH}_{3}\right), 6.63(\mathrm{~s}, 1 \mathrm{H}, \mathrm{Ph}-\mathrm{H})$, 7.01-7.12 (m, 2H, Ph-H), 7.79-7.86 (m, 2H, Ph-H).

3,4,5-Trimethoxybenzoic acid. To a solution of 3,4,5-trimethoxytoluene (1 g, $5.5 \mathrm{mmol})$ in acetone $(20 \mathrm{~mL})$ was added $\mathrm{KMnO}_{4}(0.76 \mathrm{~g}, 5.5 \mathrm{mmol})$ and water $(20 \mathrm{~mL})$ at room temperature, followed by 5 drops of concentrated sulphuric acid. More $\mathrm{KMnO}_{4}(2.28 \mathrm{~g}, 16.5 \mathrm{mmol})$ was added in portions during the reaction. The mixture was stirred for $10 \mathrm{~h}$. The precipitate was filtered off and acetone was removed in vacuo. The obtained solution was extracted with DCM $(30 \mathrm{~mL} \times 2)$ and the water layer 
was acidified to $\mathrm{pH} 2-3$ and extracted with DCM $(35 \mathrm{~mL} \times 3)$. The combined DCM layers were dried over anhydrous $\mathrm{MgSO}_{4}$, concentrated and crystallized to yield as 3,4,5-trimethoxybenzoic acid as a white solid $(0.74 \mathrm{~g}, 64 \%)$.

Morpholino(3,4,5-trimethoxyphenyl)methanone (1c). To a solution of 3,4,5-trimethoxybenzoic acid $(0.21 \mathrm{~g}, 1 \mathrm{mmol})$ and morpholine $(0.13 \mathrm{~g}, 1.5 \mathrm{mmol})$ in DCM $(20 \mathrm{~mL})$ was added EDCI $(0.23 \mathrm{~g}, 1.2 \mathrm{mmol})$ at room temperature. The mixture was stirred for $1 \mathrm{~h}$. The solution was diluted with DCM (40 mL) and washed with water $(30 \mathrm{~mL} \times 3)$. The separated organic layer was dried over anhydrous $\mathrm{MgSO}_{4}$, concentrated and crystallized to give $1 \mathrm{c}$ as a white solid $(0.17 \mathrm{~g}, 61 \%) . \mathrm{mp} 96-99^{\circ} \mathrm{C}$ (lit. 96-98 $\left.{ }^{\circ} \mathrm{C}\right)$ [14]; IR (film, cm ${ }^{-1}$ ) 3508, 3492, 2960, 2927, 2852, 1737, 1633, 1583, 1461, 1423, 1326, 1230, 1124, 1002; ${ }^{1} \mathrm{H}-\mathrm{NMR}\left(\mathrm{CDCl}_{3}, 400 \mathrm{MHz}\right) \delta(\mathrm{ppm}): 3.69(\mathrm{~m}, 8 \mathrm{H}$, morpholine- $\mathrm{H}), 3.86\left(\mathrm{~s}, 3 \mathrm{H}, \mathrm{OCH}_{3}\right), 3.88(\mathrm{~s}, 6 \mathrm{H}$, $\left.2 \mathrm{OCH}_{3}\right), 6.63(\mathrm{~s}, 2 \mathrm{H}, \mathrm{Ph}-\mathrm{H})$.

Benzotriazol-1-yl(2,3,4-trimethoxyphenyl)methanone (1d). To a solution of 3,4,5-trimethoxybenzoic acid $(0.21 \mathrm{~g}, 1 \mathrm{mmol})$ and $1 H$-benzotriazole $(0.14 \mathrm{~g}, 1.2 \mathrm{mmol})$ in DCM $(20 \mathrm{~mL})$ was added EDCI $(0.23 \mathrm{~g}, 1.2 \mathrm{mmol})$, followed by the addition of DMAP $(0.025 \mathrm{~g}, 0.2 \mathrm{mmol})$. The mixture was stirred for $1 \mathrm{~h}$, then diluted with DCM $(50 \mathrm{~mL})$ and washed by water $(30 \mathrm{~mL} \times 3)$. The organic layer was dried over anhydrous $\mathrm{MgSO}_{4}$ and concentrated. The obtained crude product was purified by column chromatograph (petroleum-ethyl acetate $\left.15: 1, \mathrm{R}_{\mathrm{f}}=0.15\right)$ to give $\mathbf{1 d}$ as a white solid $(0.24 \mathrm{~g}, 77 \%)$. $\mathrm{mp}$ 119-122 ${ }^{\circ} \mathrm{C}$ (lit. mp 126-128 ${ }^{\circ} \mathrm{C}$ ) [15]; IR (film, $\mathrm{cm}^{-1}$ ) 3442, 1737, 1705, 1587, 1450, 1373, 1134, 995, 750; ${ }^{1} \mathrm{H}-\mathrm{NMR}\left(\mathrm{CDCl}_{3}, 300 \mathrm{MHz}\right) \delta(\mathrm{ppm}): 3.96\left(\mathrm{~s}, 6 \mathrm{H}, 2 \mathrm{OCH}_{3}\right), 3.99\left(\mathrm{~s}, 3 \mathrm{H}, \mathrm{OCH}_{3}\right), 7.55-7.59$ (m, 3H, 2Ph-H, BTA-H), 7.73 (t, $J=8 \mathrm{~Hz}, 1 \mathrm{H}, \mathrm{BTA}-\mathrm{H}), 8.18$ (d, $J=8.4 \mathrm{~Hz}, 1 \mathrm{H}, \mathrm{BTA}-\mathrm{H}) .8 .38$ (d, $J=8.0 \mathrm{~Hz}, 1 \mathrm{H}, \mathrm{BTA}-\mathrm{H}) . m / z(\mathrm{EI}) 313\left(\mathrm{M}^{+}\right)$.

2-Isopropyl-6-methylpyrimidin-4-yl-3,4,5-trimethoxybenzoate (1e). To a solution of 3,4,5-trimethoxybenzoic acid $(0.21 \mathrm{~g}, 1 \mathrm{mmol})$ and 6-hydroxy-2-isopropyl-4-methylpyrimidine $(0.15 \mathrm{~g}, 1 \mathrm{mmol})$ in DCM $(10 \mathrm{~mL})$ was added EDCI $(0.28 \mathrm{~g}, 1.5 \mathrm{mmol})$. The mixture was stirred for $4 \mathrm{~h}$, then diluted with $90 \mathrm{~mL}$ of DCM. The mixture was washed by water and the organic layer was separated, dried over anhydrous $\mathrm{MgSO}_{4}$. The solvent was evaporated and the crude product was purified by chromatograph (petroleumethyl acetate $\left.10: 1, \mathrm{R}_{\mathrm{f}}=0.17\right)$ on gel silica to give $1 \mathrm{e}$ as a white solid $(0.19 \mathrm{~g}, 55 \%)$. mp $97-99{ }^{\circ} \mathrm{C}$; IR (film, $\mathrm{cm}^{-1}$ ): 2970, 2943, 2841, 1739, 1587, 1504, 1415, 1326, 1207, 1128, 974, 750. ${ }^{1} \mathrm{H}-\mathrm{NMR}$ $\left(\mathrm{CDCl}_{3}, 400 \mathrm{MHz}\right) \delta(\mathrm{ppm}): 1.35\left(\mathrm{~d}, J=6.8 \mathrm{~Hz}, 6 \mathrm{H}, 2 \mathrm{CH}_{3}\right), 2.57\left(\mathrm{~s}, 3 \mathrm{H}, \mathrm{CH}_{3}\right), 3.20(\mathrm{~m}, 1 \mathrm{H}, \mathrm{CH}), 3.94(\mathrm{~s}$, $\left.6 \mathrm{H}, 2 \mathrm{OCH}_{3}\right), 3.95\left(\mathrm{~s}, 3 \mathrm{H}, \mathrm{OCH}_{3}\right), 6.91(\mathrm{~s}, 1 \mathrm{H}$, pyrimidine-H), $7.26(\mathrm{~s}, 1 \mathrm{H}, \mathrm{Ph}-\mathrm{H}), 7.45(\mathrm{~s}, 1 \mathrm{H}, \mathrm{Ph}-\mathrm{H})$. $m / z$ (EI) $346\left(\mathrm{M}^{+}\right)$. Anal. Calc. for $\mathrm{C}_{18} \mathrm{H}_{22} \mathrm{~N}_{2} \mathrm{O}_{5}$ (346.38): C, 62.42; H, 6.40; N, 8.09; found: C, 62.43; $\mathrm{H}, 6.42 ; \mathrm{N}, 8.06$.

4-Morpholinecarbonyl chloride (2). Triphosgene (1.49 g, $5 \mathrm{mmol})$ was dissolved in DCM (150 $\mathrm{mL})$, then a solution of morpholine $(0.87 \mathrm{~g}, 10 \mathrm{mmol})$ and triethylamine $(1.52 \mathrm{~g}, 15 \mathrm{mmol})$ in DCM $(30 \mathrm{~mL})$ was slowly added dropwise in a salt-ice bath. After the addition, the reaction was monitored by TLC (iodine vapor detection) until the reaction was completed. Phosgene was blowed off by $\mathrm{N}_{2}$, then the mixture was filtered and the filtrate was concentrated to give $\mathbf{2}$ as a light-brown oil $(1.47 \mathrm{~g}, 98 \%$, with a content of about $70 \%$ ), which was used freshly in the next step without further purification. 
Phenylmorpholine-4-carboxylate (3a). To a solution of crude compound 2 (0.96 g, with a content of about $70 \%, 4.5 \mathrm{mmol}), \mathrm{Et}_{3} \mathrm{~N}(0.90 \mathrm{~g}, 9 \mathrm{mmol})$ and DMAP $(0.13 \mathrm{~g}, 1.1 \mathrm{mmol})$ in DCM (20 mL) was added a solution of phenol $(0.28 \mathrm{~g}, 3 \mathrm{mmol})$ in DCM $(10 \mathrm{~mL})$ dropwise at room temperature. The mixture was allowed to stir overnight. $100 \mathrm{~mL}$ of DCM was added and the mixture was washed successively with sat. $\mathrm{Na}_{2} \mathrm{CO}_{3}, 0.5 \mathrm{~N} \mathrm{HCl}$ and brine. The organic layer was dried over anhydrous $\mathrm{MgSO}_{4}$, concentrated to give a crude product which was purified by column chromatography (petroleum-ethyl acetate $\left.5: 1, \mathrm{R}_{\mathrm{f}}=0.30\right)$ to give $\mathbf{3 a}$ as a light-yellow solid $(0.45 \mathrm{~g}, 73 \%)$. mp $54-56{ }^{\circ} \mathrm{C}$; IR (film, $\mathrm{cm}^{-1}$ ): 2858, 1722, 1419, 1205, 1116, 1064, 856, 742, 690; ${ }^{1} \mathrm{H}-\mathrm{NMR}\left(\mathrm{CDCl}_{3}, 300 \mathrm{MHz}\right)$ $\delta$ (ppm): 3.57-3.76 (m, 8H, morpholine-H), 7.10-7.12 (m, 2H, Ph-H), 7.18-7.23 (m, 1H, Ph-H), 7.34-7.39 (m, 2H, Ph-H). $m / z(E I) 207\left(\mathrm{M}^{+}\right)$. Anal. Calc. for $\mathrm{C}_{11} \mathrm{H}_{13} \mathrm{NO}_{3}$ (207.23): C, 63.76; H, 6.32; N, 6.76; found: C, 63.71; H, 6.36; N, 6.77.

2-Isopropyl-6-methylpyrimidin-4-yl morpholine-4-carboxylate (3b). To a stirred solution of 6-hydroxy-2-isopropyl-4-methylprimidine $(0.15 \mathrm{~g}, 1 \mathrm{mmol})$ and 4-morpholinecarbonyl chloride (crude product, $0.28 \mathrm{~g}$, about $1.3 \mathrm{mmol})$ in DCM $(15 \mathrm{~mL})$ was added a solution of $\operatorname{Et}_{3} \mathrm{~N}(0.20 \mathrm{~g}, 2 \mathrm{mmol})$ in DCM $(5 \mathrm{~mL})$, followed by addition of DMAP $(0.03 \mathrm{~g}, 0.25 \mathrm{mmol})$. The mixture was stirred at room temperature for $5 \mathrm{~h}$. DCM $(80 \mathrm{~mL})$ was added and the mixture was washed sequentially with cold sat. $\mathrm{Na}_{2} \mathrm{CO}_{3}$ and water. The DCM layer was separated and dried over anhydrous $\mathrm{MgSO}_{4}$, concentrated in vacuo to give the crude product, which was purified by column chromatography (petroleum-ethyl acetate $\left.3: 1, \mathrm{R}_{\mathrm{f}}=0.21\right)$ to give $\mathbf{3 b}$ as a light-yellow oil $(0.19 \mathrm{~g}, 72 \%)$. IR (film, $\left.\mathrm{cm}^{-1}\right): 2968,2927$, 2864, 1733, 1585, 1421, 1342, 1274, 1230, 1155, 1118, 1060, 848, 746. ${ }^{1} \mathrm{H}-\mathrm{NMR}\left(\mathrm{CDCl}_{3}, 300 \mathrm{MHz}\right) \delta$ (ppm): 1.32 (d, $\left.J=6.8 \mathrm{~Hz}, 6 \mathrm{H}, 2 \mathrm{CH}_{3}\right), 2.52\left(\mathrm{~s}, 3 \mathrm{H}, \mathrm{CH}_{3}\right), 3.14(\mathrm{~m}, 1 \mathrm{H}, \mathrm{CH}), 3.58-3.78(\mathrm{~m}, 8 \mathrm{H}$, morpholine-H), $6.86\left(\mathrm{~s}, 1 \mathrm{H}\right.$, pyrimidine-H). $\mathrm{m} / z$ (EI) $265\left(\mathrm{M}^{+}\right)$. Anal. Calc. for $\mathrm{C}_{13} \mathrm{H}_{19} \mathrm{~N}_{3} \mathrm{O}_{3}(265.31)$ : C, 58.85; H, 7.22; N, 15.84; found: C, 58.78; H, 7.25; N, 15.88 .

1-Phenyl-1H-1,2,4-triazol-3-yl morpholine-4-carboxylate (3c). To a solution of 1-phenyl-1H-1,2,4triazol-3-ol (1.62 g, $10 \mathrm{mmol})$ in DCM $(50 \mathrm{~mL})$ was added $\mathrm{K}_{2} \mathrm{CO}_{3}$ powder $(2.07 \mathrm{~g}, 15 \mathrm{mmol})$. After the mixture was stirred at r.t. for $0.5 \mathrm{~h}$, a solution of 4-morpholinecarbonyl chloride (crude product, $2.8 \mathrm{~g}, 13 \mathrm{mmol})$ in DCM (15 mL) was added, followed by the addition of TBAB ( $0.64 \mathrm{~g}, 2 \mathrm{mmol})$. The mixture was allowed to stir at r.t. overnight. Another $30 \mathrm{~mL}$ of DCM was added and the mixture was washed with water $(30 \mathrm{~mL} \times 3)$. The $\mathrm{DCM}$ layer was dried over anhydrous $\mathrm{MgSO}_{4}$, concentrated in vacuo to give crude product, which was purified by column chromatography (petroleum-ethyl acetate $\left.5: 1, \mathrm{R}_{\mathrm{f}}=0.31\right)$ to give $3 \mathrm{c}$ as a light-yellow solid $(2.46 \mathrm{~g}, 90 \%) . \mathrm{mp} 114-115^{\circ} \mathrm{C}$; IR (film, $\left.\mathrm{cm}^{-1}\right)$ : 3114, 2922, 2862, 1730, 1533, 1415, 1326, 1230, 1109, 1060, 854, 759. ${ }^{1} \mathrm{H}-\mathrm{NMR}\left(\mathrm{CDC}_{13}, 400 \mathrm{MHz}\right) \delta$ (ppm): 3.65-3.78 (m, 8H, morpholine-H); 7.36 (m, 1H, Ph-H); 7.53-7.69 (m, 4H, Ph-H); 9.17 (s, 1H, triazole-H). $m / z$ (EI) $274\left(\mathrm{M}^{+}\right)$. Anal. Calc. for $\mathrm{C}_{13} \mathrm{H}_{14} \mathrm{~N}_{4} \mathrm{O}_{3}$ (274.28): C, 56.93; H, 5.14; N, 20.43; found: C, 56.92; H, 5.17; N, 20.40.

2-Chloro-1-morpholinoethanone (4). To a solution of morpholine (8.7 g, $100 \mathrm{mmol})$ in THF $(250 \mathrm{~mL})$ was added $\mathrm{K}_{2} \mathrm{CO}_{3}$ powder $(27.6 \mathrm{~g} 200 \mathrm{mmol})$. A solution of chloracetyl chloride (13.6 g, $120 \mathrm{mmol}$ ) in THF was added dropwise in an ice-water bath under stirring. After the mixture was stirred for $1 \mathrm{~h}$ at the same temperature, the morpholine was converted to a single product nearly 
quantitatively as monitored by TLC (iodine vapor detection). The reaction mixture was filtered and the filtrate was concentraed in vacuo. The residue was dissolved in dichloromethane $(200 \mathrm{~mL})$ and washed with sat. aqueous $\mathrm{Na}_{2} \mathrm{CO}_{3}$ and brine, respectively. The organic layer was dried over anhydrous $\mathrm{MgSO}_{4}$ and concentrated to give colorless oil which was used in the next steps without further purification.

General procedure for the preparation of (3,4-dimethoxyphenyl)(4-halogenated-phenyl)methanones 5a and 5b. To a suspension of $\mathrm{AlCl}_{3}(0.81 \mathrm{~g}, 6 \mathrm{mmol})$ in DCM $(20 \mathrm{~mL})$ was added a solution of 1,2-dimethoxybenzene $(0.57 \mathrm{~g}, 5 \mathrm{mmol})$ in DCM $(10 \mathrm{~mL})$ dropwise in an ice-water bath $\left(0-5{ }^{\circ} \mathrm{C}\right)$, followed by the slow addition of a solution of the appropriate 4-halogenated benzoyl chloride $(6 \mathrm{mmol})$ in DCM dropwise while the temperature was maintained under $10^{\circ} \mathrm{C}$. The mixture was stirred at the same temperature for $2.5 \mathrm{~h}$. DCM $(100 \mathrm{~mL})$ was added and the solution was washed successively with $0.5 \mathrm{~N}$ aqueous $\mathrm{HCl}(20 \mathrm{~mL})$ and water. The organic layer was dried over anhydrous $\mathrm{MgSO}_{4}$ and filtered. Removal of the solvent gave a white solid which was crystallized from methanol to separately give $\mathbf{5 a}$ and $\mathbf{5 b}$ in yields of $76 \%$ and $73 \%$.

(3,4-Dimethoxyphenyl)(4-halogenated phenyl)methanone oximes $\mathbf{6 a}$ and $\mathbf{6} \mathbf{b}$. To a refluxing solution of compounds $\mathbf{5 a}$ or $\mathbf{5 b}(10 \mathrm{mmol})$ in anhydrous ethanol was added $\mathrm{CH}_{3} \mathrm{COONa}(8.23 \mathrm{~g}, 100 \mathrm{mmol})$ and $\mathrm{NH}_{2} \mathrm{OH} \cdot \mathrm{HCl}(7.03 \mathrm{~g}, 100 \mathrm{mmol})$ in portions. The mixture was stirred at reflux for $2.5 \mathrm{~h}$. The reaction was completed and produced only one product as indicated by TLC. After the solid was filtered off, the filtrate was concentrated in vacuo to afford a residue, which was dissolved in DCM $(250 \mathrm{~mL})$, then washed with water $(100 \mathrm{~mL} \times 2)$. The organic layer was dried over anhydrous $\mathrm{MgSO}_{4}$. The solvent was removed in vacuo to give $\mathbf{6 a}$ or $\mathbf{6 b}$ as a white solid with the yield of higher than $95 \%$.

2-((((3,4-Dimethoxyphenyl)(4-fluorophenyl)methylene)amino)oxy)-1-morpholinoethanone (7a). To a solution of $6 \mathrm{a}(0.28 \mathrm{~g}, 1 \mathrm{mmol})$ and compound $4(0.17 \mathrm{~g}, 1 \mathrm{mmol})$ in THF $(30 \mathrm{~mL})$ was added $\mathrm{K}_{2} \mathrm{CO}_{3}$ powder $(0.14 \mathrm{~g}, 1 \mathrm{mmol})$ and $\mathrm{KI}(1.66 \mathrm{~g}, 1 \mathrm{mmol})$. The mixture was stirred at reflux for $5 \mathrm{~h}$. After the precipitate was filtered off and the solvent in the filtrate was evaporated in vacuo, DCM (100 mL) was added to the residue. The resulting solution was washed with water $(100 \mathrm{~mL} \times 2)$, dried over anhydrous $\mathrm{MgSO}_{4}$ and concentrated. The obtained crude product was purified by column chromatograph using petroleum-ethyl acetate (5:1) as the eluent to give $7 \mathbf{a}$ as a white solid ( $0.30 \mathrm{~g}, 72 \%)$. $\mathrm{R}_{\mathrm{f}}=0.31$ (petroleum-ethyl acetate $=5: 1$, very close to the $\mathrm{R}_{\mathrm{f}}$ of $7 \mathrm{~b}$ ); mp $109-112{ }^{\circ} \mathrm{C}$; IR (film, $\mathrm{cm}^{-1}$ ): $3853,3745,2958,2825,2854,2360,1658,1600,1442,1413,1139,1022$.

2-((((3,4-Dimethoxyphenyl)(4-chlorophenyl)methylene)amino)oxy)-1-morpholinoethanone (7b) was prepared by the same procedure as described for $7 \mathbf{a}$ as a white solid $(0.31 \mathrm{~g}, 74 \%)$. $\mathrm{R}_{\mathrm{f}}=0.31$ (petroleum: ethyl acetate 5:1); $\mathrm{mp} 112-115^{\circ} \mathrm{C}$; IR (film, $\mathrm{cm}^{-1}$ ): 2690, 2931, 2856, 1666, 1600, 1512, 1234, 1139, 1022, 844; ${ }^{1} \mathrm{H}-\mathrm{NMR}\left(\mathrm{CDCl}_{3}, 400 \mathrm{MHz}\right) \delta(\mathrm{ppm})$ : 3.42-3.66(m, 8H, morpholine-H), 3.86-3.92 (m, 6H, 2OCH $), 4.84\left(\mathrm{~s}, 2 \mathrm{H}, \mathrm{CH}_{2}\right), 6.76-7.03(\mathrm{~m}, 3 \mathrm{H}, \mathrm{Ph}-\mathrm{H}), 7.10-7.17$ (m, 2H, Ph-H), 7.45-7.48 (m, 2H, Ph-H). $m / z(E I) 418\left(\mathrm{M}^{+}\right)$. Anal. Calc. for $\mathrm{C}_{21} \mathrm{H}_{23} \mathrm{ClN}_{2} \mathrm{O}_{5}$ (418.87): C, 60.22; H, 5.53; N, 6.69; found: C, 60.25; H, 5.56; N, 6.63.

(3,4-Dimethoxyphenyl)(4-fluorophenyl)methanone O-morpholine-4-carbonyl oxime (7c). To a solution of 6a (0.28 g, $1 \mathrm{mmol}), \mathrm{Et}_{3} \mathrm{~N}(0.15 \mathrm{~g}, 1.5 \mathrm{mmol})$ and DMAP $(0.03 \mathrm{~g}, 0.25 \mathrm{mmol})$ in DCM (15 mL) was 
added a solution of crude compound $2(0.32 \mathrm{~g}$, with a content of $70 \%, 1.5 \mathrm{mmol})$ in DCM $(10 \mathrm{~mL})$ dropwise in ice-water bath. Then the mixture was refluxed for $2 \mathrm{~h}$. DCM $(70 \mathrm{~mL})$ was added and the mixture was washed with water. The DCM layer was dried over anhydrous $\mathrm{MgSO}_{4}$, concentrated to give a crude product which was purified by column chromatograph (petroleum-ethyl acetate 2:1, $\mathrm{R}_{\mathrm{f}}=0.26$, very close to the $\mathrm{R}_{\mathrm{f}}$ of $\left.\mathbf{7 d}\right)$ to give $7 \mathrm{c}$ as a white solid $(0.33 \mathrm{~g}, 85.1 \%) . \mathrm{mp} 136-139{ }^{\circ} \mathrm{C}$; IR (film, $\mathrm{cm}^{-1}$ ): 1733, 1600, 1514, 1417, 1232, 1139, 1022.

(4-Chlorophenyl)(3,4-dimethoxyphenyl)methanone O-morpholine-4-carbonyl oxime (7d). Compound 7d was prepared by the same procedure as described for $7 \mathbf{c}$ as a white solid $(0.36 \mathrm{~g}, 89.1 \%)$. $\mathrm{R}_{\mathrm{f}}=0.26$ (petroleum-ethyl acetate 2:1); mp 130-134 ${ }^{\circ} \mathrm{C} ;{ }^{1} \mathrm{H}-\mathrm{NMR}\left(\mathrm{CDCl}_{3}, 400 \mathrm{MHz}\right) \delta$ (ppm): 3.21-3.54 (m, $8 \mathrm{H}$, morpholine- $\mathrm{H}), 3.84\left(\mathrm{~s}, 3 \mathrm{H}, \mathrm{OCH}_{3}\right), 3.95\left(\mathrm{~s}, 3 \mathrm{H}, \mathrm{OCH}_{3}\right), 6.85-6.94(\mathrm{~m}, 3 \mathrm{H}, \mathrm{Ph}-\mathrm{H}), 7.02-7.07$ (m, 2H, Ph-H), 7.58-7.62 (m, 2H, Ph-H). $m / z$ (EI) $404\left(\mathrm{M}^{+}\right)$. Anal. Calc. for $\mathrm{C}_{20} \mathrm{H}_{21} \mathrm{ClN}_{2} \mathrm{O}_{5}$ (404.84): C, 59.33; H, 5.23; N, 6.92; found: C, 59.37; H, 5.24; N, 6.87.

(3,4-Dimethoxyphenyl)(4-halogenated)methanols $\mathbf{8 a}$ and $\mathbf{8 b}$. To a solution of compound $\mathbf{5}$ (10 mmol) in DCM $(40 \mathrm{~mL})$ and methanol $(10 \mathrm{~mL})$ was added $\mathrm{NaBH}_{4}$ powder $(0.57 \mathrm{~g}, 15 \mathrm{mmol})$ in portions at room temperature. The mixture was refluxed for $1 \mathrm{~h}$. The mixture was poured into a beaker and quenched by addition of cold $0.2 \mathrm{~N} \mathrm{HCl}$. After the precipitate was filtered off, the filtrate was extracted with DCM $(100 \mathrm{~mL} \times 2)$. The combined organic layer was washed with brine, dried over anhydrous $\mathrm{MgSO}_{4}$, filtered and concentrated in vacuo to give $\mathbf{8 a}$ or $\mathbf{8 b}$ as a white powder in nearly quantitative yield that was used directly for the next steps.

2-((3,4-Dimethoxyphenyl)(4-fluorophenyl)methoxy)-1-morpholinoethanone (9a). To a solution of 8a $(0.52 \mathrm{~g}, 2 \mathrm{mmol})$ in THF $(25 \mathrm{~mL})$ was added NaH $(76 \%, 0.13 \mathrm{~g}, 4 \mathrm{mmol})$, followed by the addition of a solution of $4(0.33 \mathrm{~g}, 2 \mathrm{mmol})$ in THF $(10 \mathrm{~mL})$ dropwise at room temperature. The mixture was stirred for $2 \mathrm{~h}$. The mixture was filtered and filtrate was concentrated. The residue was dissolved in DCM $(150 \mathrm{~mL})$ and washed with water. The organic layer was dried over anhydrous $\mathrm{MgSO}_{4}$, filtered and concentrated in vacuo to give a crude product, which was purified by column chromatography on silica gel (petroleum-ethyl acetate $\left.3: 1, \mathrm{R}_{\mathrm{f}}=0.13\right)$ to give $9 \mathrm{a}$ as a colorless oil $(0.71 \mathrm{~g}, 91.6 \%)$. IR (film, cm ${ }^{-1}$ ): 3531, 2931, 2856, 1651, 1508, 1463, 1261, 1234, 1112, 1026, 846; ${ }^{1} \mathrm{H}-\mathrm{NMR}\left(\mathrm{CDCl}_{3}\right.$, $400 \mathrm{MHz}) \delta(\mathrm{ppm}): 3.46-3.67\left(\mathrm{~m}, 8 \mathrm{H}\right.$, morpholine-H), 3.83(s, 3H, $\left.\mathrm{OCH}_{3}\right), 3.87\left(\mathrm{~s}, 3 \mathrm{H}, \mathrm{OCH}_{3}\right)$, 4.09-4.18 (s, 2H, CH $), 5.45(\mathrm{~s}, 1 \mathrm{H}, \mathrm{CH}), 6.81-6.86(\mathrm{~m}, 3 \mathrm{H}, \mathrm{Ph}-\mathrm{H}), 6.99-7.03(\mathrm{~m}, 2 \mathrm{H}, \mathrm{Ph}-\mathrm{H})$, 7.26-7.33 (m, 2H, Ph-H). m/z (EI) $389\left(\mathrm{M}^{+}\right)$. Anal. Calc. for $\mathrm{C}_{21} \mathrm{H}_{24} \mathrm{FNO}_{5}$ (389.42): C, 64.77; H, 6.21; N, 3.60; found: C, 64.81; H, 6.20; N, 3.57.

2-((4-Chlorophenyl)(3,4-dimethoxyphenyl)methoxy)-1-morpholinoethanone (9b) The title compound was prepared using the same procedure as described for 9a to give a light-yellow oil $(83.9 \%)$. $\mathrm{R}_{\mathrm{f}}=0.13$ (petroleum-ethyl acetate 3:1); IR (film, $\mathrm{cm}^{-1}$ ): 3491, 2956, 2925, 2854, 1651, 1510, 1461, 1263, 1234, 1112, 1026, 846; ${ }^{1} \mathrm{H}-\mathrm{NMR}\left(\mathrm{CDCl}_{3}, 400 \mathrm{MHz}\right) \delta(\mathrm{ppm}): 3.46-3.67$ (m, 8H, morpholine-H), 3.83 (s, $\left.3 \mathrm{H}, \mathrm{OCH}_{3}\right), 3.87\left(\mathrm{~s}, 3 \mathrm{H}, \mathrm{OCH}_{3}\right), 4.09-4.18\left(\mathrm{~m}, 2 \mathrm{H}, \mathrm{CH}_{2}\right), 5.45(\mathrm{~s}, 1 \mathrm{H}, \mathrm{CH}), 6.81-6.86(\mathrm{~m}, 3 \mathrm{H}, \mathrm{Ph}-\mathrm{H})$, 6.99-7.01 (m, 2H, Ph-H), 7.26-7.33 (m, 2H, Ph-H). m/z (EI) $405\left(\mathrm{M}^{+}\right)$. Anal. Calc. for $\mathrm{C}_{21} \mathrm{H}_{24} \mathrm{ClNO}_{5}$ (405.87): C, 62.14; H, 5.96; N, 3.45; found: C, 62.19; H, 5.92; N, 3.43. 
(4-Halogenated phenyl)(3,4-dimethoxyphenyl)methanamines $\mathbf{1 0 a}$ and $\mathbf{1 0 b}$. To a solution of compound 6a or $6 \mathbf{b}(2 \mathrm{mmol})$ in ethanol $(10 \mathrm{~mL})$ was added a $3 \%$ aqueous solution of ammonia, $\mathrm{NH}_{4} \mathrm{OAC}(0.26 \mathrm{~g}$, $3.6 \mathrm{mmol})$ and water $(10 \mathrm{~mL})$. The mixture was refluxed and $\mathrm{Zn}$ powder $(0.65 \mathrm{~g}, 10 \mathrm{mmol})$ was added in portions during the reaction, after being refluxed for $6 \mathrm{~h}$, the solid was filtered off. The solvent in the filtrate was evaporated, and DCM $(100 \mathrm{~mL})$ and water $(100 \mathrm{~mL})$ were added. The DCM layer was separated, washed with water, dried over $\mathrm{MgSO}_{4}$ and concentrated to give $\mathbf{1 0 a}$ or $\mathbf{1 0 b}$ as a colorless and viscous oil $(0.47 \mathrm{~g}, 91 \%$ for $\mathbf{1 0 a}, 0.51 \mathrm{~g}, 92 \%$ for $\mathbf{1 0 b})$, which was used for the next step without further purification.

2-(((4-Fluorophenyl)(3,4-dimethoxyphenyl)methyl)amino)-1-morpholinoethanone (11a). To a mixture of 10a $(0.26 \mathrm{~g}, 1 \mathrm{mmol}), \mathrm{K}_{2} \mathrm{CO}_{3}(0.24 \mathrm{~g}, 2 \mathrm{mmol})$ and $\mathrm{KI}(0.17 \mathrm{~g}, 1 \mathrm{mmol})$ in $\mathrm{CH}_{3} \mathrm{CN}(30 \mathrm{~mL})$ was added dropwise a solution of compound $4(2.3 \mathrm{~g}, 1.5 \mathrm{mmol})$ in $\mathrm{CH}_{3} \mathrm{CN}(10 \mathrm{~mL})$. The mixture was stirred at room temperature for about $15 \mathrm{~h}$. After the solid was filtered off, the solvent in the filtrate was removed in vacuo. The residue was dissolved in DCM $(100 \mathrm{~mL})$ and water $(100 \mathrm{~mL})$. The organic layer was washed with brine $(50 \mathrm{~mL} \times 2)$, dried over anhydrous $\mathrm{MgSO}_{4}$, filtered and concentrated to give a crude product which was purified by column chromatography (petroleum-ethyl acetate 1:3, $\left.\mathrm{R}_{\mathrm{f}}=0.27\right)$ to afford 11a as a white powdery solid $(0.29 \mathrm{~g}, 72 \%) . \mathrm{mp} 167-170{ }^{\circ} \mathrm{C}$; IR (film, $\mathrm{cm}^{-1}$ ): 3550, 3492, 2958, 2923, 2854, 1651, 1456, 1232, 1114, 1029, 848, 732; ${ }^{1} \mathrm{H}-\mathrm{NMR}\left(\mathrm{CDCl}_{3}, 300 \mathrm{MHz}\right)$ $\delta$ (ppm): 3.23-3.34 (m, 4H, morpholine-H), 3.54-3.65 (m, 7H, morpholine- $\left.\mathrm{H},-\mathrm{CH}_{2},-\mathrm{CH}\right), 3.84$ $\left(\mathrm{s}, 3 \mathrm{H}, \mathrm{OCH}_{3}\right), 3.85\left(\mathrm{~s}, 3 \mathrm{H}, \mathrm{OCH}_{3}\right), 5.35(\mathrm{~m}, 1 \mathrm{H},-\mathrm{NH}), 6.78(\mathrm{~d}, J=11.2 \mathrm{~Hz}, 1 \mathrm{H}, \mathrm{Ph}-\mathrm{H}), 6.91$ (d, $J=11.2 \mathrm{~Hz}, 1 \mathrm{H}, \mathrm{Ph}-\mathrm{H}), 6.95-7.03(\mathrm{~m}, 3 \mathrm{H}, \mathrm{Ph}-\mathrm{H}), 7.40-7.46(\mathrm{~m}, 2 \mathrm{H}, \mathrm{Ph}-\mathrm{H}) . m / z(\mathrm{EI}) 388\left(\mathrm{M}^{+}\right)$. Anal. Calc. for: $\mathrm{C}_{21} \mathrm{H}_{25} \mathrm{FN}_{2} \mathrm{O}_{4}$ (388.43): C, 64.93; H, 6.49; N, 7.21; found: C, 64.95; H, 6.45; N, 7.23.

2-(((4-Fluorophenyl)(3,4-dimethoxyphenyl)methyl)amino)-1-morpholinoethanone (11b). The title compound was prepared as a white solid $(0.29 \mathrm{~g}, 71 \%)$ by the same procedure as described for 11a.

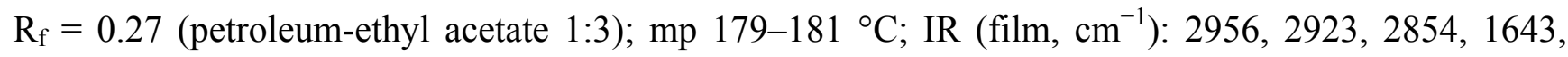
$1506,1454,1267,1232,1114,1029,848$.

$\mathrm{N}$-((4-Chlorophenyl)(3,4-dimethoxyphenyl)methyl)morpholine-4-carboxamide (11c). To a solution of compound 10b $(0.28 \mathrm{~g}, 1 \mathrm{mmol})$ in DCM $(15 \mathrm{~mL})$ was added $\mathrm{Et}_{3} \mathrm{~N}(0.15 \mathrm{~g}, 1.5 \mathrm{mmol})$ and DMAP $(0.025 \mathrm{~g}, 0.2 \mathrm{mmol})$, followed by the addition of a solution of compound 2 in DCM $(5 \mathrm{~mL})$. The mixture was stirred at room temperature overnight, then DCM $(60 \mathrm{~mL})$ was added. The organic layer was washed with water $(50 \mathrm{~mL} \times 2)$ and dried over anhydrous $\mathrm{MgSO}_{4}$. The $\mathrm{DCM}$ was evaporated in vacuo to give a crude product which was purified by column chromatography (petroleum- ethyl acetate $\left.1: 1, \mathrm{R}_{\mathrm{f}}=0.34\right)$ to give compound 11c as a white solid $(0.28 \mathrm{~g}, 71.8 \%) . \mathrm{mp} 90-93{ }^{\circ} \mathrm{C}$; IR (film, $\mathrm{cm}^{-1}$ ): 2956, 2923, 2852, 1627, 1510, 1461, 1253, 1116, 1026, 831, 746, 657; ${ }^{1} \mathrm{H}-\mathrm{NMR}\left(\mathrm{CDCl}_{3}\right.$, $400 \mathrm{MHz}) \delta(\mathrm{ppm}): 3.36-3.40(\mathrm{~m}, 4 \mathrm{H}$, morpholine-H), 3.67-3.71 (m, 4H, morpholine-H), 3.81 (s, 3H, $\left.\mathrm{OCH}_{3}\right), 3.85\left(\mathrm{~s}, 3 \mathrm{H}, \mathrm{OCH}_{3}\right), 4.88(\mathrm{~d}, J=6.6 \mathrm{~Hz}, 1 \mathrm{H}, \mathrm{CH}), 6.06(\mathrm{~d}, J=6.6 \mathrm{~Hz}, 1 \mathrm{H}, \mathrm{NH}), 6.73-6.83(\mathrm{~m}$, $3 \mathrm{H}, \mathrm{Ph}-\mathrm{H}), 6.98-7.03$ (m, 2H, Ph-H), 7.20-7.26 (m, 2H, Ph-H). $m / z$ (EI) $390\left(\mathrm{M}^{+}\right)$. Anal. Calc. for: $\mathrm{C}_{20} \mathrm{H}_{23} \mathrm{ClN}_{2} \mathrm{O}_{4}$ (390.86): C, 61.46; H, 5.93; N, 7.17; found: C, 61.49; H, 5.95; N, 7.12. 


\subsection{Biological Tests}

\subsubsection{Antifungal Methods}

The synthetic compounds were dissolved in DMSO and sterilized water (containing 1\% Tween) and diluted with PDA in a Petri dish. The antifungal activity was tested in vitro by the poisoned food technique $[22,23]$ at a final concentration of $50 \mu \mathrm{g} / \mathrm{mL}$. The widely used and commercial available fungicides dimethomorph and flumorph were used as positive controls.

\subsubsection{Antibacterial Methods}

About $10 \mathrm{~mL}$ of sterilized 2216E medium was poured into the sterilized Petri dish. After solidification, $1 \mathrm{~mL}$ of inoculum of each test vibrio was added and sprayed uniformly. Then a $4 \mathrm{~mm}$ well was made in the centre of each plate using a sterilized cork-borer. Each well received $20 \mu \mathrm{L}$ of solution of the tested compounds dissolved in DMSO. The diameters were measured after the plates were incubated at $28{ }^{\circ} \mathrm{C}$ for about $24 \mathrm{~h}$. Two antibiotics, streptomycin and gentamicin sulfate were used as the positive controls. The blank control (DMSO) was of no inhibition to the vibrios.

\section{Conclusions}

A series of benzophenone compounds was designed and synthesized. The biological activity evaluation indicated that the synthesized compounds were quite potent on most of the tested fungi, but much less effective on the five tested vibrios. At least one of the novel benzophenone derivatives gave higher activity than flumorph and dimethomorph towards the tested fungi. Compounds $\mathbf{1 a}$ and $\mathbf{1 b}$ exhibited relatively good activity against five fungi, making them interesting leads for the design and optmization of new fungicides. Six compounds (1c, 1e, 3b, 3c, 7c and 11a) had effects on all of the tested fungi from different genera and showed better wide-spectrum activity. A $\mathrm{Cl}$ atom, three methoxy groups on the benzene ring and a pyrimidine group might be favorable for increasing the antifungal activity. The screened compound $\mathbf{7 b}$ might be a better candidate than carbendazim to inhibit Fusarium oxysporum $f$. sp. vasinfectum. The structure-activity relationships were discussed preliminarily and should be somewhat helpful for further studies to design more potent derivatives and discovery better fungicides with different modes of action.

\section{Supplementary Information}

Supplementary materials can be accessed on: http:/www.mdpi.com/1420-3049/16/11/9739/s1.

\section{Acknowledgments}

We are profoundly grateful to Zhijin Fan and his group from Nankai University for their great help and generous suggestions concerning in antifungal bioactivity tests. The authors also thank Zongjun Du for supplying the vibrios for the assays. 


\section{References and Notes}

1. Keith, J.B.; Derek, W.H. Fungicide Resistance: The Assessment of Risk; GCPF: Brussels, Belgium, 1998; pp. 6-13.

2. Schmitt, M.R.; Carzaniga, R.; Cotter, H.V.T.; O’Connell, R.; Hollomon, D. Microscopy reveals disease control through novel effects on fungal development: A case study with an earlygeneration benzophenone fungicide. Pest Manag. Sci. 2006, 62, 383-392.

3. Capriotti, M.; Gentili, E.; Vecchio, A.D.; Balzaretti, G.; Fagnani, A. Metrafenone (vivando): New Fungicide for Grape Powdery Mildew Control. Proceedings of the Phytopathological Meeting, Riccione, RN, Italy, March 2006.

4. Scannavini, M.; Cavazza, F.; Franceschelli, F. Trials of several years for grape powdery mildew control with metrafenone and kresoxim-methyl+boscalid in Emilia Romagna. Proceedings of the Phytopathological Meeting, Riccione, RN, Italy, March 2006.

5. Koehle, H.; Opalski, K.; Huckelhoven, R. Metrafenone-The First Benzophenone-Type Fungicide: Profile and Mode of Action; Hering, O., Brandt, B., Eds.; Deutsche Pflanzenschutztagung: Hamburg, Germany, 2004; pp. 335-336.

6. Opalski, K.S.; Tresch, S.; Kogel, K.H.; Grossmann, K.; Kohle, H.; Huckelhoven, R. Metrafenone: Studies on the mode of action of a novel cereal powdery mildew fungicide. Pest Manag. Sci. 2006, 62, 393-401.

7. Yuan, S.K.; Liu, X.L.; Si, N.G.; Dong, J.; Gu, B.G.; Jiang, H. Sensitivity of Phytophthora infestans to flumorph: In vitro determination of baseline sensitivity and the risk of resistance. Plant Pathol. 2006, 55, 258-263.

8. Blum, M.; Boehler, M.; Randall, E.; Young, V.; Csukai, M.; Kraus, S.; Moulin, F.; Scalliet, G.; Avrova, A.O.; Whisson, S.C.; Fonne-Pfister, R. Mandipropamid targets the cellulose synthaselike PiCesA3 to inhibit cell wall biosynthesis in the oomycete plant pathogen, Phytophthora infestans. Mol. Plant Pathol. 2010, 11, 227-243.

9. Qin, Z.H.; Mu, C.W.; Mao, S.F.; Dong, Y.H.; Li, N.; Zhang, S.S. Preparation of 4-[3-(pyridin-4yl)-3-phenylacryl]morpholine Derivtives as Fungicides. CN Patent 566095A, 19 January, 2005.

10. Huang, Q.C.; Ye, Z.Y. Claracter and mode of action of dimethomorph. Nong Yao Ke Xue Yu Guan Li 2000, 21, 28-31.

11. Meanwell, N.A. Synopsis of some recent tactical application of bioisosteres in drug design. J. Med. Chem. 2011, 54, 2529-2591.

12. Venkataraman, K. Prosess for the Preparation of Substituted Benzophenones. US Patent 2001/0031753 A1, 18 October, 2001.

13. Milburn, R.R.; Snieckus, V. Ortho-anisylsulfonyl as a protecting group for sencondary amines: Mild $\mathrm{Ni}^{0}$-catalyzed hydrodesulfonylation. Angew. Chem. Int. Ed. 2004, 116, 910-912.

14. Yang, X.D.; Zeng, X.H.; Zhao, Y.H.; Wang, X.Q.; Pan, Z.Q.; Li, L.; Zhang, H.B. Silica gel-mediated amide bond formation: An environmentally benign method for liquid-phase synthesis and cytotoxic activities of amides. J. Comb. Chem. 2010, 12, 307-310.

15. Fu, J.; Yang, Y.; Zhang, X.W.; Mao, W.J.; Zhang, Z.M.; Zhu, H.L. Discovery of 1h-benzo[d][1,2,3]triazol-1-yl 3,4,5-trimethoxybenzoate as a potential antiproliferative agent by inhibiting histone deacetylase. Bioorg. Med. Chem. 2010, 18, 8457-8462. 
16. Sun, L.; Wu, J.; Zhang, L.; Luo, M.; Sun, D.Q. Synthesis and antifungal activities of some novel pyrimidine derivatives. Molecules 2011, 16, 5618-5628.

17. Ulloa, M.; Hutmacher, R.B.; Davis, R.M.; Wright, S.D.; Percy, R.; Marsh, B. Breeding for fusarium wilt race 4 resistance in cotton under field and greenhouse conditions. J. Cotton Sci. 2006, 10, 114-127.

18. Pandey, A.; Naik, M.M.; Dubey, S.K. Organic metabolites produced by vibrio parahaemolyticus strain an3 isolated from goan mullet inhibit bacterial fish pathogens. Afr. J. Biotechnol. 2010, 9 , 7134-7140.

19. Sarter, S.; Nguyen, H.N.K.; Hung, L.T.; Lazard, J.; Montet, D. Antibiotic resistance in gram-negative bacteria isolated from farmed catfish. Food Control 2007, 18, 1391-1396.

20. Dang, H.; Zhang, X.; Song, L.; Chang, Y.; Yang, G. Molecular determination of oxytetracyclineresistant bacteria and their resistance genes from mariculture environments of China. J. Appl. Microbiol. 2007, 103, 2580-2592.

21. Isnansetyo, A.; Istiqomah, I.; Muhtadi; Sinansari, S.; Hernawan, R.K.; Triyanto; Widada, J. A potential bacterial biocontrol agent, strain $\mathrm{s}_{2} \mathrm{~V}_{2}$ against pathogenic marine vibrio in aquaculture. World J. Microbiol. Biotechnol. 2009, 25, 1103-1113.

22 Damodiran, M.; Muralidharan, D.; Perumal, P.T. Regioselective synthesis and biological evaluation of bis(indolyl)methane derivatized 1,4-disubstituted 1,2,3-bistriazoles as anti-infective agents. Bioorg. Med. Chem. Lett. 2009, 19, 3611-3514.

23. Fan, Z.J.; Shi, Z.G.; Zhang, H.K.; Liu, X.F.; Bao, L.L.; Ma, L.; Zuo, X.; Zheng, Q.X.; Mi, N. Synthesis and biological activity evaluation of 1,2,3-thiadiazole derivatives as potential elicitors with highly systemic acquired resistance. J. Agric. Food Chem. 2009, 57, 4279-4286.

Sample Availability: Contact the authors.

(C) 2011 by the authors; licensee MDPI, Basel, Switzerland. This article is an open access article distributed under the terms and conditions of the Creative Commons Attribution license (http://creativecommons.org/licenses/by/3.0/). 